\title{
Effects of Thiamethoxam-Treated Seed on Mexican Bean Beetle (Coleoptera: Coccinellidae), Nontarget Arthropods, and Crop Performance in Southwestern Virginia Snap Beans
}

\author{
L. Nottingham, ${ }^{1,6}$ T. P. Kuhar, ${ }^{2}$ T. Kring, ${ }^{2}$ D. A. Herbert, ${ }^{3}$ R. Arancibia, ${ }^{4}$ and P. Schultz ${ }^{5}$ \\ ${ }^{1}$ Washington State University Tree Fruit Research and Extension Center 1100 N Western Avenue, Wenatchee, WA 98801, ${ }^{2}$ Department \\ of Entomology, Virginia Tech, Blacksburg, VA 24061-0319, 'Virginia Tech Tidewater Agricultural Research and Extension Center, \\ Holland, VA, ${ }^{4}$ Virginia Tech Eastern Shore Agricultural Research and Extension Center, Painter, VA, ${ }^{5}$ Virginia Tech Hampton Roads \\ Agricultural Research and Extension Center, Virginia Beach, VA, and ${ }^{6}$ Corresponding author, e-mail: louis.nottingham@wsu.edu
}

Subject Editor: David Onstad

Received 1 April 2017; Editorial decision 25 August 2017

\begin{abstract}
Thiamethoxam is a neonicotinoid insecticide commonly applied directly to the seeds (seed-treatment) of commercial snap beans, Phaseolus vulgaris $\mathrm{L}$. While previous studies have examined target and nontarget effects of thiamethoxam seed-treatments in snap beans and other crops, to our knowledge, none have been conducted in agroecosystems predominated by the pest Mexican bean beetle, Epilachna varivestis Mulsant (Coleoptera: Coccinellidae). This study examined the effects of thiamethoxam-treated snap beans on E. varivestis, other arthropods, and crop performance in southwestern Virginia. Greenhouse experiments were conducted to evaluate residual toxicity of treated snap beans to E. varivestis and a key predator, Podisus maculiventris (Say) (Hemiptera: Pentatomidae). Treated plants were highly toxic to E. varivestis at $13 \mathrm{~d}$, moderately toxic from 16 to $20 \mathrm{~d}$, and minimally toxic at $24 \mathrm{~d}$. P. maculiventris was unaffected by exposure to treated plants or by feeding on E. varivestis that consumed treated plants. Small plot field experiments in 2014 and 2015 showed no significant effects of thiamethoxam seed-treatments on E. varivestis densities, other arthropods, crop injury, or yield. In 2016, planting was delayed by persistent rain, resulting in early $E$. varivestis colonization. In this year, thiamethoxam-treated plants had significantly lower densities and feeding injury from $E$. varivestis, followed by significantly higher yields. Natural enemies were unaffected by seed-treatments in all field experiments. These experiments demonstrated that thiamethoxam seed-treatments provide control of $E$. varivestis when beetles infest fields within 2 to 3 wk after planting; but otherwise provide negligible advantages. Negative effects from thiamethoxam seed-treatments on nontarget arthropods appear minimal for snap beans in this region.
\end{abstract}

Key words: Seed treatment, Epilachna varivestis, Phaseolus vulgaris, natural enemy, agroecosystem

The use of neonicotinoid insecticides applied as a seed coating ("seed-treatments") are prolific in commercial agriculture due to their ease of use and efficacy against early season pests (Douglas and Tooker 2015). However, this prophylactic control method is under scrutiny because of wide-scale implementation and potential nontarget effects, particularly on pollinators (Douglas and Tooker 2015, 2016; Lundin et al. 2015). Neonicotinoid seed-treatments are attractive to growers for multiple reasons. Seeds are delivered pretreated by the manufacturer and have lower use rates of active ingredient than in-furrow sprays, soil drenches, or foliar applications of the same insecticide (Taylor et al. 2001), making this method comparably easy, safe, and inexpensive to the user. Neonicotinoids move systemically throughout developing plants to provide control of a broad range of insect pests, while having relatively low mammalian toxicity (Maienfisch et al. 2001, Nault et al. 2004, Koch et al. 2005, Reisig et al. 2012). Some neonicotinoids have been shown to alter gene expression in plants associated with physiological responses to stress, such as triggering salicylic acid (SA) pathways (Ford et al. 2010, Szczepaniec et al. 2013, Afifi et al. 2015). Eliciting stress response pathways like SA can result in increased plant vigor (Afifi et al. 2015) and heightened defenses against insect feeding (Cooper and Horton 2015); however, alterations to defense pathways can also render plants more susceptible certain pests like spider mites (Szczepaniec et al. 2013).

The ease-of-use, affordability, and expected benefits of neonicotinoid seed-treatments have arguably led to their over-use in 
commercial agriculture. Additionally, seed-treatments encourage growers to use insecticides prophylactically, instead of when/if pests reach economic thresholds, which goes against key principles of integrated pest management (IPM) (Stern 1973, Philips et al. 2014, Douglas and Tooker 2015). Overuse may result in pest resistance to insecticides, reductions in beneficial arthropods, secondary pest outbreaks, and more pesticides moving off-site (Radcliffe and Hutcheson 2009, Prabhaker et al. 2011, Seagraves and Lundgren 2012). Because this insecticide class and application method is prone to over-use, is important for the industry to fully understand the risks and expected outcomes in specific growing systems (different crops, pest complexes, climates, geographies, etc.).

Thiamethoxam, a broad-spectrum neonicotinoid insecticide, is one of the most common insecticides used as a seed-treatment in snap beans, Phaseolus vulgaris L. Thiamethoxam seed-treatments are known to control a variety of snap bean pests, such as potato leafhopper, Empoasca fabae (Harris) (Hemiptera: Cicadellidae), bean leaf beetle, Cerotoma trifurcata (Forster) (Coleoptera: Chrysomelidae), seedcorn maggot, Delia platura (Meigen) (Diptera: Anthomyiidae), and soybean thrips, Neohydatothrips variabilis (Beach) (Thysanoptera: Thripidae) (Eckenrode et al. 1973, Nault et al. 2004, Koch et al. 2005, Reisig et al. 2012). In the central Appalachian Mountains of the Mid-Atlantic U.S., the primary economic pest of snap beans is Mexican bean beetle, Epilachna varivestis Mulsant (Coleoptera: Coccinellidae) (Fess 2008, Nottingham et al. 2016). To our knowledge, no research has been conducted on the effects of thiamethoxam-treated snap beans in agroecosystems dominated by this pest. The goal of this study was to quantify the effects of thiamethoxam seed-treatments in snap beans on: 1) E. varivestis densities and feeding injury; 2) toxicity to Podisus maculiventris (Say) (Hemiptera: Pentatomidae), a common predator of E. varivestis; 3) nonpests and beneficial arthropods found in the field; and 4) overall crop outcome (stand, plant health, and yield).

\section{Materials and Methods}

\section{Treatments}

For all field and laboratory experiments, pretreated 'Caprice' snap bean seeds were purchased from Stokes Seeds (Buffalo, NY) at the beginning of each year. Seeds arrived treated with either thiamethoxam and fungicides or with only fungicides. Thiamethoxam- and fungicide-treated seeds (hereafter referred to as 'TT') were coated in thiamethoxam (Cruiser, Syngenta Crop Protection, Greensboro, NC) applied at $46.88 \mathrm{~g}$ a.i./100 $\mathrm{kg}$ of seed and a combination of fungicides (Captan 400, Bayer CropScience, Research Triangle Park, NC; AGStreptomycin, Bayer CropScience; Allegiance FL, Bayer CropScience; Thiram, Bayer CropScience) applied at standard commercial rates. Seeds with fungicides only (hereafter referred to as 'FO') were coated with the same fungicide products and rates as TT seeds.

\section{Lab Experiments}

\section{Residual Toxicity to E. varivestis}

In the summer of 2016, experiments were conducted to determine the approximate length of time after planting that snap beans grown from TT seeds remained toxic to E. varivestis adults and late instars (third and fourth). Adults and late instars were tested independently (two experiments using only adults, two using only larvae). The first adult experiment was initiated on 10 June 2016; the second was initiated on 23 June 2016. The first larval experiment was initiated on 26 June 2016; the second was initiated on 10 July 2016. For all experiments, snap bean plants were grown from TT and FO seeds in a glass green house at Virginia Tech in Blacksburg, VA, with temperatures not exceeding $29^{\circ} \mathrm{C}\left(85^{\circ} \mathrm{F}\right)$. E. varivestis adults and late instars were field collected from untreated snap beans, brought back to the greenhouse, and stored in $12.5-\mathrm{cm}$ Petri dishes with moistened filter paper for $24 \mathrm{~h}$ before use in experiments. Snap bean seeds were sown in 72 -cell plastic growing trays $(6-\mathrm{cm}$ diam cells) and watered daily with overhead irrigation. At first true leaf stage, three plants of the same treatment were transplanted into plastic cup containers, $12-\mathrm{cm}$ diam and $20-\mathrm{cm}$ deep with $10 \mathrm{~cm}$ of potting soil (W.Y. Industries, North Bergen, NJ). Beetles (either adults or larvae depending on the experiment) were placed on plants in each container using a small paintbrush, then containers were covered with a mesh lid. Six beetles were used per container for adults and larvae at every plant age tested (days-after-sowing[DAS]) except for adults at 13 DAS, where only five adults were used due to low field population (repeated at 13 DAS in the second adult experiment for consistency). Each container having three plants and five or six beetles represented one experimental unit. There were four replicates per treatment. Numbers of living and dead individuals were counted $72 \mathrm{~h}$ after introduction. The procedure was repeated with new plants and beetles at 3- and 4-d increments until no differences in mortality were observed among treatments.

\section{Direct and Secondary Toxicity to $P$. maculiventris}

In the summer of 2016, P. maculiventris adults were acquired from a laboratory colony at the USDA in Beltsville, MD. The insects were kept in $30 \times 30 \mathrm{~cm}$ mesh cages (1466AV, BioQuip Products, Inc) with about 50 adults per cage. Each cage had one plastic cup, 12-cm diam and 20-cm deep (W. Y. Industries, North Bergen, NJ), containing 20 snap bean plants for food and oviposition habitat. Waxworm larvae (family: Pyralidae) were obtained from a local pet store and fed to $P$. maculiventris (10 per cage, twice weekly). Fifth instar P. maculiventris from the F1 generation and following generation were used in these experiments.

Experiments were conducted to examine the acute toxicity of snap beans grown from TT seeds to $P$. maculiventris. Both direct toxicity (via exposure to or ingestion of treated snap beans) and secondary toxicity (via ingestion of intoxicated prey) were tested because $P$. maculiventris is known to feed on snap bean plants and E. varivestis larvae, pupae, and adults (Howard and Landis 1936, O’Neil and Wiedenmann 1990). Toxicity of seed-treatment grown plants to P. maculiventris was evaluated in three ways: 1 ) exposure of $P$. maculiventris to plants alone; 2 ) exposure to prey (E. varivestis third instars and adults) alone; and 3) exposure to plants and prey together. 'Caprice' snap bean plants were grown from seeds in the same manner described in residual toxicity assays. TT and FO were the treatments tested for all experiments.

Direct toxicity of TT snap beans to $P$. maculiventris was examined in two identical experiments. An experimental unit was a 30 $\times$ 30-cm mesh cage (1466AV, BioQuip Products, Inc) containing 12, 10-d-old snap bean plants (either TT or FO) grown in a 12-cell plastic germination tray $(6-\mathrm{cm}$ diam cells). Five, fifth instar P. maculiventris were placed on bean foliage in each cage. There were four replicates per treatment ( $n=20$ nymphs per replicate) in each experiment. Cages were checked for living and dead P. maculiventris every day for $6 \mathrm{~d}$; which was sufficient time for surviving nymphs to molt into adults.

Secondary toxicity from TT snap beans to P. maculiventris was examined in two experiments, one using E. varivestis adults and the other with third instars as prey. E. varivestis adults and larvae were collected from untreated beans in the field and placed in cages with either FO or TT snap beans (four cages for each treatment). Beetles fed for $6 \mathrm{~h}$ before being used in experiments. Plants fed to beetles 


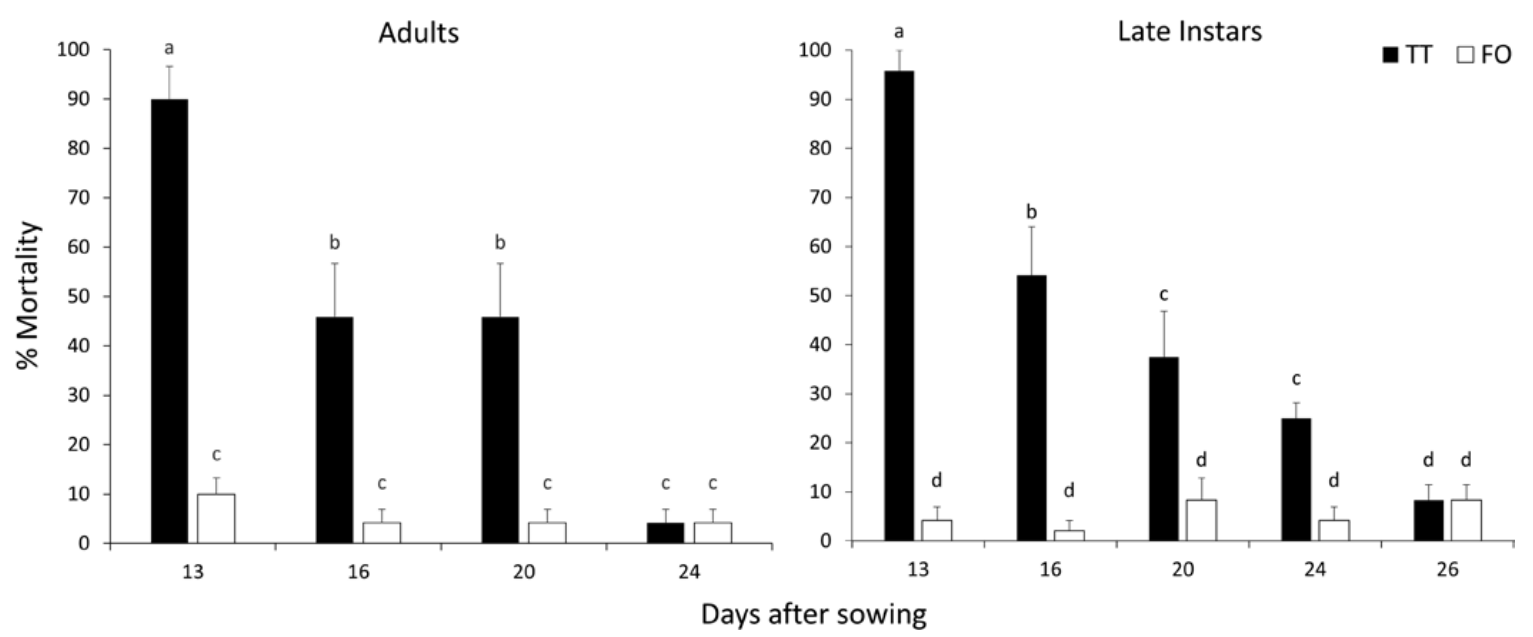

Fig. 1. Average percent mortality (number of dead beetles out of total) ( $\pm \mathrm{SEM}$ ) for adult and late instar E. varivestis after $72 \mathrm{~h}$ on plants grown from seeds treated with thiamethoxam and fungicides (TT) and fungicides only (FO). The x-axis indicates the age of the plants (days after sowing) upon introduction of beetles. Values within each graph that are not sharing a common letter are different $(P<0.05)$ according to Fisher's Least Significant Difference (LSD).

Table 1. Podisus maculiventris mortality rating scale, used to quantify the occurrence and speed of a secondary poisoning event into a single value

\begin{tabular}{lc}
\hline Podisus maculiventris found dead at time & Rating \\
\hline $24 \mathrm{~h}$ & 6 \\
$48 \mathrm{~h}$ & 5 \\
$72 \mathrm{~h}$ & 4 \\
$96 \mathrm{~h}$ & 3 \\
$120 \mathrm{~h}$ & 2 \\
$144 \mathrm{~h}$ & 1 \\
Survived & 0 \\
\hline
\end{tabular}

were 10- to 13-d old, ensuring that TT plants were within the time frame of high toxicity to E. varivestis; determined from residual toxicity experiments (Fig. 1). P. maculiventris nymphs were isolated without food for about $48 \mathrm{~h}$. One P. maculiventris nymph and two E. varivestis were placed into a plastic cup container, $12-\mathrm{cm}$ diam and $10-\mathrm{cm}$ tall, with a partially mesh lid (experimental unit). There were 16 replicates per treatment ( $n=16$ nymphs per replicate). Two E. varivestis were added to each container per day for $6 \mathrm{~d}$; previously added beetles, alive and dead, were removed. One water-soaked cotton wick was added and replaced daily. Containers were checked for dead $P$. maculiventris every $24 \mathrm{~h}$. A mortality rating system was developed to quantify how long nymphs survived (Table 1). This scale was based on the idea that shorter survival times were more indicative of mortality from secondary toxicity. Consumption of $E$. varivestis was not documented for each P. maculiventris; and therefore, it is possible that predation did not occur in every experimental unit. However, dead adult and larval E. varivestis were found in all containers, and predation was witnessed in both treatments, suggesting that all $P$. maculiventris fed on beetles. Additionally, previous research has demonstrated that $P$. maculiventris readily feed on $E$. varivestis larvae and adults in cages staged in laboratories and greenhouses (Howard and Landis 1936, O’Neil 1989, Wiedenmann and O’Neil 1991).

The final experiments incorporated plants and prey together to more accurately resemble a field scenario. The design was similar to plants-only (direct toxicity) experiments. There were four cages for both treatments (FO and TT), each having 12, 10-d-old plants and five fifth instar $P$. maculiventris per cage ( $n=20$ per replicate). Each day, 10 adult E. varivestis were collected from untreated plants in the field and placed on the plants in each cage. Those from the previous day, alive and dead, were removed. Numbers of living and dead $P$. maculiventris were recorded after $7 \mathrm{~d}$ of exposure. This experiment was repeated with E. varivestis third instars as prey instead of adults.

\section{Field Experiments \\ Design}

Field experiments were conducted at Virginia Tech's Kentland Farm in Whitethorne, VA $\left(37.2013^{\circ} \mathrm{N},-80.5656^{\circ} \mathrm{W}\right)$. One field experiment was conducted each summer in 2014, 2015, and 2016. Experimental units (hereafter referred to as 'plots') for all experiments were consecutive rows of snap beans grown from either TT or FO seeds. 2014 and 2016 experiments were randomized complete blocks, and 2015 was a generalized randomized block. The number of replicates, plot size, and spacing changed from year to year depending on available land space. Changing plot locations, sizes, and row spacings annually provides a more rigorous assessment of the transferability of treatment effects to different cropping systems.

For all experiments, fields were prepared for planting by broadcasting 10-10-10 fertilizer at a rate of $112-\mathrm{kg}$ per ha, followed by an application of pre-emergence herbicides, halosulfuron-methyl (Sandea 75DF, Gowan Company, Yuma, AZ), and S-metolachlor (Dual Magnum, Syngenta, Greensboro, NC), at 55.4-ml a.i./ha and 0.59-liter a.i./ha, respectively. Additional weeding was performed by hand as needed for the duration of experiments. Irrigation was supplied as needed using drip tape running alongside each row.

The 2014 experimental design was a randomized complete block with eight plots (four replicates per treatment) arranged in four blocks. Snap bean seeds were planted approximately one per $6.1 \mathrm{~cm}$ using a hand-pushed mechanical seeder (EarthWay, Bristol, IN) on 8 May. Each plot was eight 7.6-m long rows. Rows within plots were separated by $45 \mathrm{~cm}$ of bare soil; plots within blocks were separated by $2 \mathrm{~m}$ of bare soil. Blocks were separated by at least $100 \mathrm{~m}$ of various crops and uncultivated areas. The 2015 experimental design was a generalized randomized block with 16 plots (eight replicates per treatment) arranged in two blocks, planted on 18 May. Plot area and between-row spacing remained the same as 2014; however, in-row spacing was wider, with seeds planted by hand at approximately one every $12.5 \mathrm{~cm}$. Plots were separated by $2 \mathrm{~m}$ of bare soil, and blocks were separated by approximately $200 \mathrm{~m}$. The 2016 experiment was 
a randomized complete block design with six plots (three replicates per treatment) arranged in three blocks. Seeds were planted on 26 May at one every $6.1 \mathrm{~cm}$ using an EarthWay push seeder. Plots were eight $13.7-\mathrm{m}$ long rows with $36 \mathrm{~cm}$ of bare soil between rows. Blocks were located on the same $140 \times 8 \mathrm{~m}$ bed, with $5 \mathrm{~m}$ of bare soil separation between blocks.

\section{Insect Sampling}

Plots were sampled for various insects using three techniques: visual plant inspections, vacuum samples, and pitfall traps. All samples were performed once per week from 10 June through 8 July in 2014, from 4 June through 10 July in 2015, and from 9 June through 19 July in 2016. Visual samples were performed using two methods, one for counting potato leafhopper nymphs, E. fabae (Harris) (Hemiptera: Cicadellidae) and thrips (consisting mostly of soybean thrips, $N$. variabilis [Beach]), and another for counting all other insects. Leafhoppers and thrips were sampled by arbitrarily selecting and visually inspecting 30 bean leaves per plot, counting all individuals. For all other insects including E. varivestis life stages (eggs, late instars [third and fourth combined], pupae and adults), visual samples were conducted by inspecting 10 arbitrarily selected plants per plot, and counting all individual insects. In 2015, only potato leafhopper and thrips were sampled via visual plant inspections; all other insects were sampled using vacuuming or pitfall traps.

Vacuum samples were performed in all field experiments using a modified leaf blower vacuum (Stihl, Virginia Beach, VA), with the intake tube attached to the suction fan for arthropod collection. A fine-mesh, 3.8-liter paint strainer bag (SB-501, MasterCraft, South El Monte, CA) was attached to the end of the tube to catch arthropods from the bean canopy. For each sample, 10 plants per plot were arbitrarily selected and vacuumed for approximately $2 \mathrm{~s}$ per plant. Bagged arthropods were immediately brought back to the laboratory and stored in a freezer before being identified. Vacuum samples were conducted after visual samples on the same day.

Pitfall sampling was conducted in all field experiments. Pitfall traps were made from plastic cup containers, $12-\mathrm{cm}$ diam and $20-\mathrm{cm}$ deep (W. Y. Industries, North Bergen, NJ). Containers were buried in the ground and filled with 0.4 liters of soapy water. Traps were deployed for 4 d each week from 10 June through 8 July in 2014, 4 June through 10 July in 2015, and 9 June through 19 July in 2016. Arthropods in traps were collected and brought back to the laboratory for identification.

Stand, Plant Health, Yield, and Pod Damage

Stand counts of all plants in plots were recorded at first trifoliate stage for all field experiments. Yield samples were taken at pod maturity, 58-62 d after planting, from the center two rows of each plot; half of each row was sampled. All pods were removed from plants by hand and weighed on an electronic scale (Adventurer Pro, Ohaus Corp, Parsippany, NJ). For each row, the total number of plants were counted and the exact length of row (distance from first to last plant stem) was measured. The percentage of pods damaged by E. varivestis was determined by arbitrarily selecting 100 pods per plot and rating each as damaged or undamaged. Damaged pods were those with feeding scars at least $1 \mathrm{~cm}$ (Nottingham and Kuhar 2016). Normalized difference vegetation index (NDVI), reported here as plant health, was evaluated in 2015 and 2016 only at flowering stage. Plant health measurements were obtained using a hand-held NDVI sensor (GreenSeeker, Trimble Navigation Limited, Sunnyvale, CA) held facing the ground at hip height while the sampler walked the entire row. The device calculates the proportion of green vegetative tissue to total area.

\section{Data Analysis}

All data were subject to statistical analysis using the software JMP Pro 11 (SAS Institute Inc. 2007). Normality was tested using a Shapiro-Wilk W test (Goodness-of-fit test). Data that did not fit a normal distribution were transformed to fit a normal distribution using the formula: $\sqrt[2]{(\text { sample value })+0.375}$ (Zar 2010). Residual toxicity was analyzed by repeated measures using a mixed-model multiple comparisons test followed by Student's $t$ (Fisher's LSD) all pairwise comparison. Percent mortality was the dependent variable, treatment and DAS were fixed effects, and random effects were individual experimental runs (first and second experiment). Significance was accepted when $P<0.05$. Adults and larvae were analyzed separately. For all other experiments, treatment effects were tested using analysis of variance (ANOVA), and significance was accepted when $P<0.05$. Treatment was a fixed effect and the independent variable in all experiments. Locational blocking was a fixed effect used in field experiment models only. The interaction effect between treatment and block was a fixed effect used in experiments with in-block replication (generalized randomized block design for 2015 field tests). Dependent variables were $P$. maculiventris mortality, cumulative arthropod densities per season, average arthropod densities per sample date (E. varivestis and thrips only), NDVI ratings, yield, and proportions of damaged pods.

\section{Results and Discussion}

\section{Greenhouse Assays}

Residual Toxicity to E. varivestis

These assays elucidate the approximate amount of time that TT snap beans will control E. varivestis adults and larvae (Fig. 1). Percent

Table 2. Mortality values of Podisus maculiventris by exposure to treated plants (direct poisoning), prey that fed on treated plants (secondary poisoning), and treated plants and Epilachna varivestis prey together

\begin{tabular}{lcc}
\hline Exposed to: & Thiamethoxam + fungicides & Fungicides only \\
(FO)
\end{tabular}

\footnotetext{
${ }^{a}$ Five $P$. maculiventris individuals per replicate $(n=20)$. Values are the average $( \pm$ SEM) percent mortality per replicate.
}

${ }^{b}$ One $P$. maculiventris per replicate $(n=16)$. Values are the average $( \pm$ SEM) mortality rating (see Table 1$)$ per replicate. 
Table 3. Cumulative mean $( \pm$ SEM) densities of arthropods in plots of snap beans with and without thiamethoxam seed treatment in southwestern Virginia

\begin{tabular}{|c|c|c|c|c|c|}
\hline & $\begin{array}{c}\text { Thiamethoxam }+ \text { fungicides } \\
\text { (TT) }\end{array}$ & $\begin{array}{l}\text { Fungicide only } \\
\text { (FO) }\end{array}$ & $P$ value & $F$ & df \\
\hline \multicolumn{6}{|l|}{2014} \\
\hline \multicolumn{6}{|l|}{ Herbivores } \\
\hline E. varivestis adults $\mathrm{vs}$ & $11.19 \pm 1.55$ & $10.71 \pm 0.88$ & ns & & \\
\hline E. varivestis egg masses $\mathrm{VS}$ & $6.85 \pm 0.33$ & $7.99 \pm 1.26$ & ns & & \\
\hline E. varivestis late instars ${ }^{\mathrm{VS}}$ & $9.59 \pm 2.04$ & $9.19 \pm 0.77$ & ns & & \\
\hline Potato leafhopper nymphs vs & $8.45 \pm 0.73$ & $11.37 \pm 1.21$ & ns & & \\
\hline Potato leafhopper adults Vac & $24.92 \pm 2.54$ & $24.42 \pm 1.62$ & ns & & \\
\hline Thrips vs & $14.35 \pm 2.82$ & $19.19 \pm 3.46$ & ns & & \\
\hline \multicolumn{6}{|l|}{ Predators } \\
\hline Orius insidiosus $\mathrm{Vac}$ & $14.32 \pm 1.35$ & $13.82 \pm 1.35$ & ns & & \\
\hline Damsel bugs (Hemiptera: Nabidae) Vac & $6.62 \pm 0.59$ & $6.79 \pm 0.98$ & ns & & \\
\hline Ladybeetles Vac & $4.13 \pm 0.55$ & $4.11 \pm 0.37$ & ns & & \\
\hline Ground beetles (Coleoptera: Carabidae) ${ }^{\mathrm{P}}$ & $7.40 \pm 0.44$ & $8.14 \pm 1.11$ & ns & & \\
\hline Spiders (Araneae) Vac & $21.00 \pm 5.87$ & $20.25 \pm 2.32$ & ns & & \\
\hline Spiders ${ }^{P}$ & $10.84 \pm 1.07$ & $9.83 \pm 1.24$ & ns & & \\
\hline \multicolumn{6}{|l|}{2015} \\
\hline \multicolumn{6}{|l|}{ Herbivores } \\
\hline E. varivestis adults $\mathrm{Vac}$ & $6.15 \pm 0.50$ & $6.34 \pm 0.30$ & ns & & \\
\hline E. varivestis egg masses & - & - & & & \\
\hline E. varivestis late instars $\mathrm{Vac}$ & $6.35 \pm 0.89$ & $7.38 \pm 0.99$ & ns & & \\
\hline Potato leafhopper nymphs vs & $6.06 \pm 0.27$ & $5.92 \pm 0.42$ & ns & & \\
\hline Potato leafhopper adults Vac & $18.07 \pm 1.12$ & $17.59 \pm 1.07$ & ns & & \\
\hline Thrips vs & $12.04 \pm 0.27$ & $16.65 \pm 0.85$ & $0.0013^{*}$ & 26.47 & 1,15 \\
\hline \multicolumn{6}{|l|}{ Predators } \\
\hline Orius insidiosus Vac & $3.12 \pm 0.26$ & $3.07 \pm 0.21$ & ns & & \\
\hline Damsel bug Vac & $2.84 \pm 0.31$ & $2.34 \pm 0.17$ & ns & & \\
\hline Ladybeetle Vac & $2.23 \pm 0.16$ & $2.05 \pm 0.10$ & ns & & \\
\hline Ground beetle $^{\mathrm{P}}$ & $10.74 \pm 0.85$ & $10.13 \pm 0.39$ & ns & & \\
\hline Spiders Vac & $3.58 \pm 0.26$ & $3.61 \pm 0.36$ & ns & & \\
\hline Spiders ${ }^{P}$ & $6.36 \pm 0.41$ & $6.42 \pm 0.31$ & ns & & \\
\hline \multicolumn{6}{|l|}{2016} \\
\hline \multicolumn{6}{|l|}{ Herbivores } \\
\hline E. varivestis adults $\mathrm{VS}$ & $24.90 \pm 1.20$ & $28.09 \pm 1.24$ & ns & & \\
\hline E. varivestis egg masses $\mathrm{VS}$ & $22.61 \pm 0.51$ & $25.38 \pm 0.82$ & ns & & \\
\hline E. varivestis late instars $\mathrm{VS}$ & $25.38 \pm 3.60$ & $63.67 \pm 2.86$ & $0.0004 *$ & 2703.0 & 1,4 \\
\hline Potato leafhopper nymphs ${ }^{\mathrm{VS}}$ & $2.39 \pm 0.07$ & $2.52 \pm 0.11$ & ns & & \\
\hline Potato leafhopper adults Vac & $23.48 \pm 1.57$ & $25.55 \pm 0.84$ & ns & & \\
\hline Thrips vs & $2.24 \pm 0.08$ & $2.45 \pm 0.07$ & ns & & \\
\hline \multicolumn{6}{|l|}{ Predators } \\
\hline Orius insidiosus Vac & $6.69 \pm 1.12$ & $5.11 \pm 0.38$ & ns & & \\
\hline Damsel bugs Vac & $3.12 \pm 0.11$ & $2.83 \pm 0.27$ & ns & & \\
\hline Ladybeetles Vac & $2.58 \pm 0.19$ & $2.33 \pm 0.27$ & ns & & \\
\hline Ground beetles ${ }^{P}$ & $8.59 \pm 0.60$ & $9.48 \pm 0.34$ & ns & & \\
\hline Spiders Vac & $4.04 \pm 0.37$ & $4.97 \pm 0.60$ & ns & & \\
\hline Spiders ${ }^{P}$ & $8.93 \pm 0.42$ & $12.07 \pm 1.03$ & ns & & \\
\hline
\end{tabular}

${ }^{\mathrm{VS}}$ Visual plant inspection of 10 plants per plot.

${ }^{\mathrm{Vac}}$ Vacuum (reversed leaf blower) sampling method.

${ }^{\mathrm{P}}$ Pitfall trap sampling method summed between two pitfall traps per plot. Cumulative average density was calculated by summing the average density values from each plot across all sample dates in a season.

"Values are significantly different $(P<0.05)$ according to an ANOVA.

ns $=$ Values are not significantly different $(P<0.05)$ according to an ANOVA.

mortality of beetles fed TT beans was significantly higher than those fed FO beans from 13 to 20 DAS for adults and 13 to 24 DAS for larvae. Percent mortality resulting from TT plants declined as plants aged for both adults (from 90 to $5 \%$ ) and larvae (from 96 to $8 \%$ ), while mortality from FO plants remained the same for all DAS for adults and larvae (between 5 and $10 \%$ for both). In summary, TT beans were highly toxic to E. varivestis adults and larvae up to $13 \mathrm{~d}$ (first true leaf to first trifoliate stage), moderately toxic from 16 to $20 \mathrm{~d}$ (1-3 trifoliate stage), and minimally, or not at all, toxic at 24 $\mathrm{d}$ and beyond.

This information suggests that thiamethoxam seed treatments will protect snap beans from E. varivestis for approximately 2 to 3 


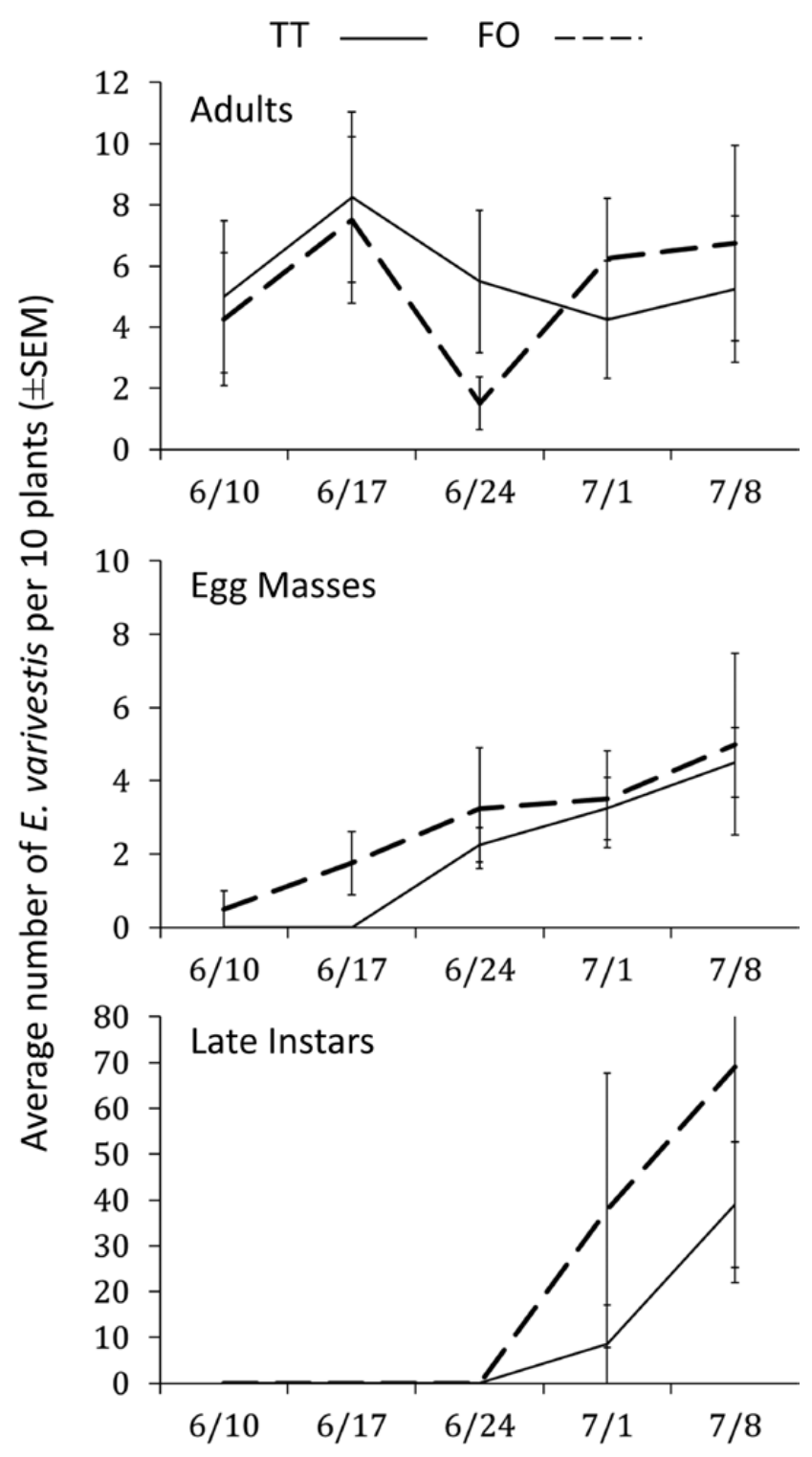

Fig. 2. Average densities ( $\pm \mathrm{SEM}$ ) of $E$. varivestis adults, egg masses and late instars per 10 snap bean plants grown from seeds treated with thiamethoxam and fungicides (TT) and fungicides only (FO) in southwest Virginia in 2014. Values within a sample date marked with * are statistically different $(P<0.05)$ according to ANOVA.

wk after seedlings emerge. In Virginia, beans are generally planted in early to mid-April (immediately after the last frost), while E. varivestis usually does not infest until late May or early June. It is therefore unlikely that using thiamethoxam-treated seeds will control $E$. varivestis in an ordinary planting situation because the pest and the control method do not overlap. However, planting beans in the late spring or early summer is not unusual. Logistical or weather constrains can cause planting delays; also, many growers plant beans throughout the season to allow for multiple harvests. In these situations, using treated seeds may successfully protect young plants from E. varivestis damage.

Direct and Secondary Toxicity to $P$. maculiventris

Mortality of $P$. maculiventris was not significant among treatments for any type of exposure (plants alone, E. varivestis alone, or plants
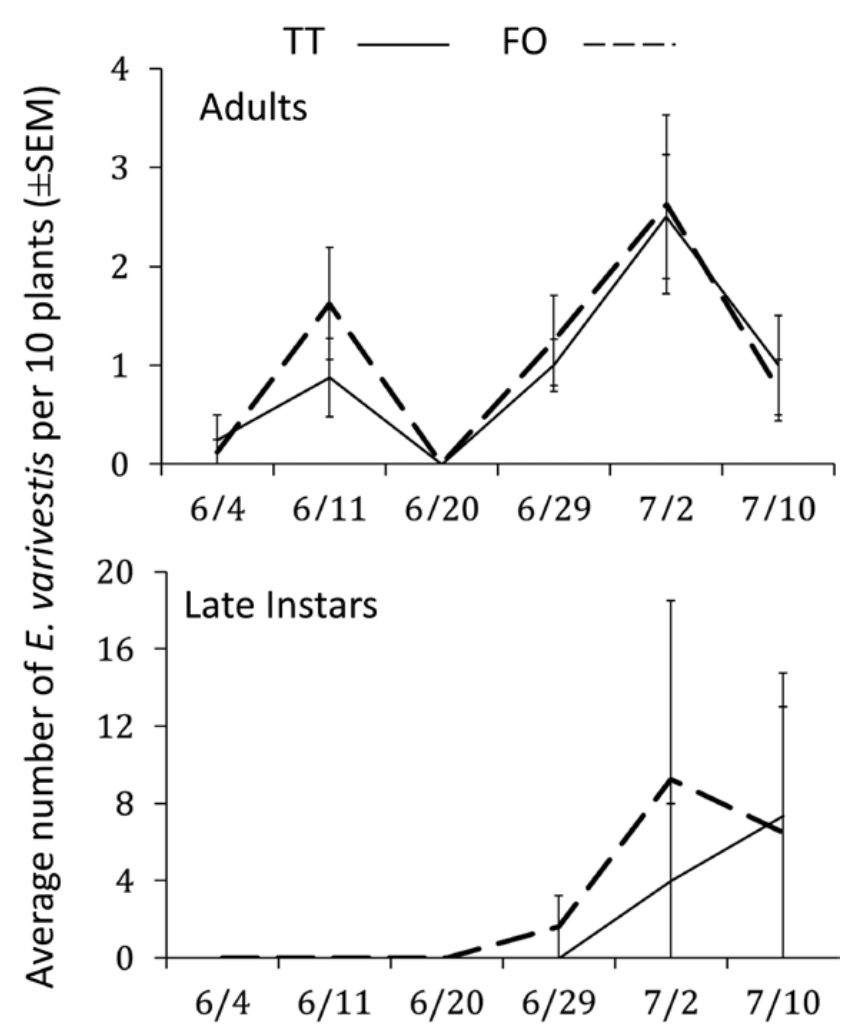

Fig. 3. Average densities ( \pm SEM) of $E$. varivestis adults and late instars per 10 snap bean plants grown from seeds treated with thiamethoxam and fungicides (TT) and fungicides only (FO) in southwest Virginia in 2015. Epilachna varivestis eggs were not sampled in 2015. Epilachna varivestis sampling in this year was only performed by vacuuming, which does not effectively capture eggs. Values within a sample date marked with * are statistically different $(P<0.05)$ according to ANOVA.

and E. varivestis together) (Table 2). No differences were observed in the developmental time of $P$. maculiventris from fifth instar to adult among treatments (data not shown). The plants used in these experiments were 10 to 13 DAS to evaluate the highest potential for toxicity to $P$. maculiventris. These experiments suggest that TT snap beans have a low risk for causing acute mortality to $P$. maculiventris. Nevertheless, more work should be performed to test sublethal effects of seed treatments on P. maculiventris, such as adult longevity, feeding voracity, fecundity, and offspring survivorship. It is also important to note that predator populations on small diverse farms like those found in southwestern Virginia can more rapidly recover from nontarget effects of pesticide (either lethal or sublethal), while large monoculture systems will experience more stable and severe impacts.

\section{Field Experiments}

Insects

Across three seasons, the only arthropods affected by treatment were E. varivestis and thrips. There were no detectable differences in densities of any predatory arthropods, and no secondary pest outbreaks occurred.

Thrips were affected by treatment in 2015 only, in which there were significantly fewer thrips in TT-treated plots (Table 3). ANOVAs used to evaluate thrips densities at individual sample dates revealed population differences in the first $2 \mathrm{wk}$ of sampling, at first true leaf stage on 4 June $(\mathrm{FO}=15.89 \pm 2.67, \mathrm{TT}=0.75 \pm 0.37 ; P<$ 
$0.0001 ; F=9.79 ; \mathrm{df}=1,14)$ and $1-2$ trifoliate stage on 11 June $(\mathrm{FO}$ $=13.25 \pm 2.52, \mathrm{TT}=4.38 \pm 1.74 ; P=0.0079 ; F=3.18 ; \mathrm{df}=1,14)$. Despite these differences, thrips numbers remained low overall (1-4 nymphs per trifoliate in the FO treatment) and were the same among treatments from the third week of sampling (3-5 trifoliate stage) to the end of the experiment.

Snap beans grown from TT seeds are known to control thrips up to $5 \mathrm{wk}$ in soybean, Glycine max L. (Reisig et al. 2012), and our results suggest that similar control may occur in snap beans. Soybean thrips are generally an early-occurring herbivore in Virginia (Reisig et al. 2012) and are an important food source to predators such as Orius insidiosus (Say) (Hemiptera: Anthocoridae) (Kiman and Yeargan 1985), which was the most abundant predator in our foliar samples (Table 3). Lower densities of this important food source (thrips) could, in theory, result in lower densities of O. insidiosus; however, this trend was not observed in our experiments. Direct impacts on O. insidiosus from thiamethoxam seed-treatments have been documented in previous laboratory studies, in which lethal and sublethal effects to O. insidiosus via direct exposure to thiamethoxam-treated plants were observed (Prabhaker et al. 2011, Seagraves and Lundgren 2012, Gontijo et al. 2015). Despite the potential for thiamethoxam treatments to have negative impacts on O. insidiosus via depletion of their food source (thrips), acute toxicity or sublethal effects, our experiments did not detect any impacts of thiamethoxam-grown snap beans on densities of O. insidiosus (Table 3). In our experiments, O. insidiosus were found at low densities prior to snap bean flowering; then sharply increased. By this point in the season, the concentration of thiamethoxam within bean plants was probably too low to have detectable impacts on O. insidiosus or their prey.

E. varivestis densities were only significantly different among treatments in one season: 2016. Cumulative densities of E. varivestis late instars were significantly lower in TT plots than FO plots (Table 3). Additionally, in 2016, treatment effects were detected for E. varivestis eggs, larvae, and adults on individual sample dates. Densities of adults and eggs were significantly higher in FO plots early in the season, as were concomitant densities of late instars later in the season (Fig. 4).

In 2016, plots had to be sown later than in 2014 and 2015 due to unusually persistent rain throughout April and May. The delayed planting in 2016 allowed E. varivestis to complete overwintering before bean plants emerged, so adults colonized plants much earlier in the crop cycle than in the previous years. When adult E. varivestis invaded plots, thiamethoxam was still highly potent within the TT treatment, resulting in detectable reduction in early-season oviposition and concomitant life stages. By the end of the season, E. varivestis eggs and early instars sharply increased in TT plots, past FO plots. This occurred because TT plants were much larger and healthier from the lack of early-season feeding. The late season increase in eggs and early instars in TT plots is the reason that cumulative densities of eggs and early instars were not significantly different among treatments. However, the suppression of young life stages early-on is more important to the overall suppression of late instars and damage, as is shown by significantly higher densities of late instars (Table 3 ) and amount of feeding injury (shown as plant health) (Table 4) in FO plots in 2016.

\section{Stand, Plant Health, Yield, and Pod Damage}

No treatment effects were observed for snap bean stand density, pod damage, plant health (NDVI ratings), or yield (pods/plant and pods/m of row) in 2014 and 2015 (Table 4). In 2016, plants in FO plots were visibly more damaged by E. varivestis feeding (observational). In this season, plant health and yield were significantly

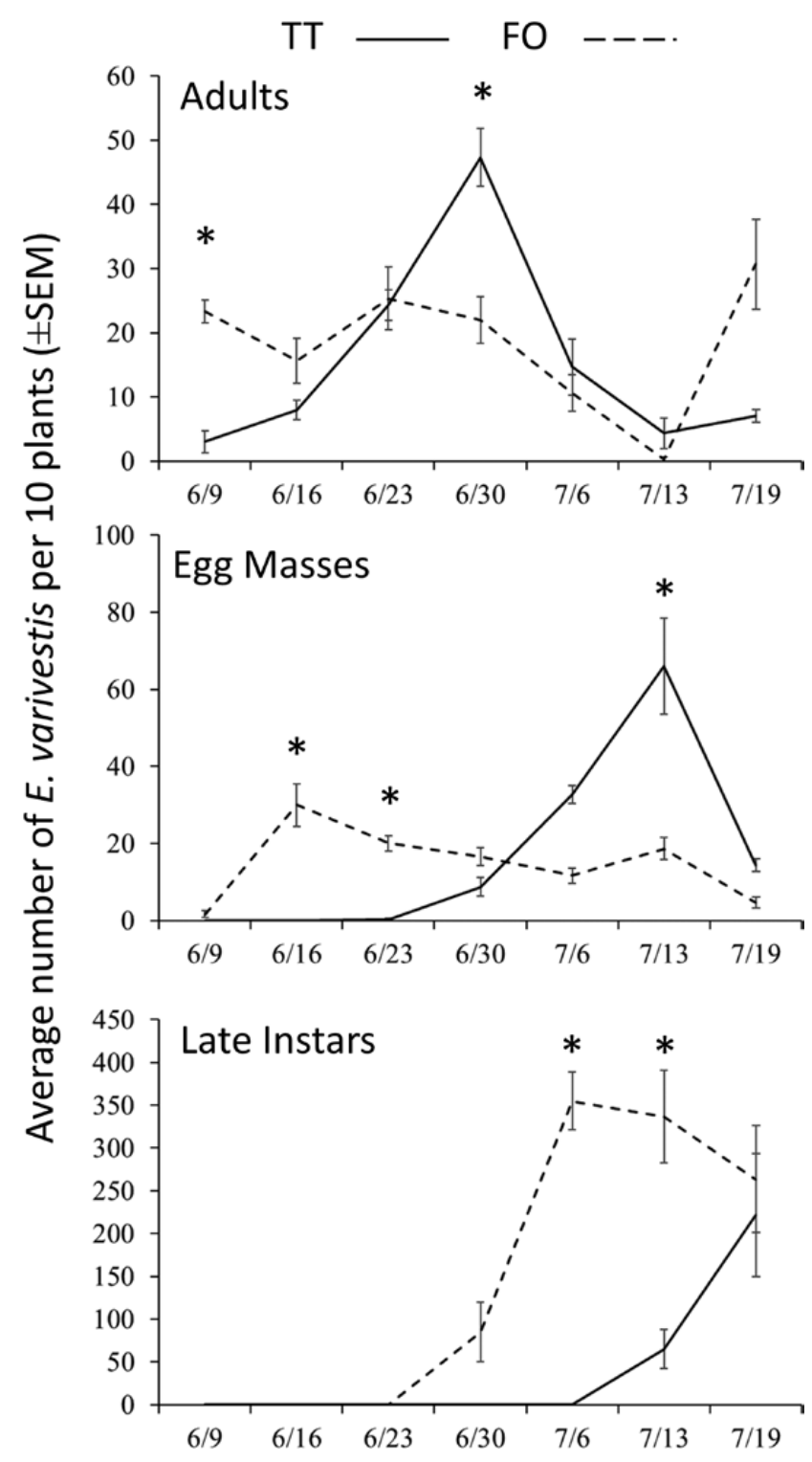

Fig. 4. Average densities ( $\pm \mathrm{SEM}$ ) of $E$. varivestis adults, egg masses, and late instars per 10 snap bean plants grown from seeds treated with thiamethoxam and fungicides (TT) and fungicides only (FO) in southwest Virginia in 2016. Values within a sample date marked with * are statistically different $(P<0.05)$ according to ANOVA.

increased by the TT treatment; however, stand density and pod damage were unaffected (Table 4).

The significant reduction in E. varivestis larvae in TT plots in 2016 was likely responsible for increases in health and yield observed in that treatment (at least partially). Capinera et al. (1987) showed that yield reductions in snap beans due to E. varivestis feeding begin at $20 \%$ defoliation, which appeared to be well below what was observed in FO plots. Nevertheless, thiamethoxam and other systemic insecticides are known to have direct effects on plants' physiology, which can impact vigor and yield as well. Previous studies have shown that the presence of clothianidin, the primary metabolite of thiamethoxam, can increase vigor in certain plant species by stimulating the immune response to biotic and abiotic stressors (Ford et al. 2010, Szczepaniec et al. 2013). Although these physiological benefits may have contributed to the increased crop performance of TT plants observed in 2016, the lack of these effects in previous seasons 
Table 4. Mean ( \pm SEM) stand counts, NDVI ratings, yield, and pod damage of snap beans with and without thiamethoxam seed treatment in southwestern Virginia

\begin{tabular}{|c|c|c|c|c|c|}
\hline & $\begin{array}{c}\text { Thiamethoxam }+ \text { fungicides } \\
\text { (TT) }\end{array}$ & $\begin{array}{l}\text { Fungicide only } \\
\text { (FO) }\end{array}$ & $P$ value & $F$ & $\mathrm{df}$ \\
\hline \multicolumn{6}{|l|}{2014} \\
\hline \multicolumn{6}{|l|}{ Stand count } \\
\hline First trifoliate stage, plants per plot & $760.0 \pm 23.1$ & $696.0 \pm 50.3$ & ns & & \\
\hline \multicolumn{6}{|l|}{ Yield } \\
\hline Pod weight (g) per plant & $29.10 \pm 8.68$ & $33.04 \pm 9.99$ & ns & & \\
\hline Pod weight $(\mathrm{g})$ per $8 \mathrm{~m}$ & $2462.5 \pm 674.0$ & $2171.3 \pm 676.5$ & ns & & \\
\hline \multicolumn{6}{|l|}{ Pod damage by E. varivestis } \\
\hline$\%$ damaged pods & $17.50 \pm 4.10$ & $19.50 \pm 6.60$ & ns & & \\
\hline \multicolumn{6}{|l|}{2015} \\
\hline \multicolumn{6}{|l|}{ Stand count } \\
\hline First trifoliate stage, plants per plot & $406.5 \pm 7.5$ & $402.0 \pm 12.2$ & ns & & \\
\hline \multicolumn{6}{|l|}{ Plant health } \\
\hline NDVI rating per plot & $0.54 \pm 0.01$ & $0.53 \pm 0.01$ & ns & & \\
\hline \multicolumn{6}{|l|}{ Yield } \\
\hline Pod weight (g) per plant & $92.48 \pm 15.5$ & $78.64 \pm 8.38$ & ns & & \\
\hline Pod weight $(\mathrm{g})$ per $2 \mathrm{~m}$ & $708.25 \pm 89.18$ & $731.88 \pm 77.17$ & ns & & \\
\hline \multicolumn{6}{|l|}{ Pod damage by E. varivestis } \\
\hline$\%$ damaged pods & $12.25 \pm 1.67$ & $11.5 \pm 1.92$ & ns & & \\
\hline \multicolumn{6}{|l|}{2016} \\
\hline \multicolumn{6}{|l|}{ Stand count } \\
\hline First trifoliate stage, plants per plot & $1004.66 \pm 41.52$ & $884.66 \pm 40.08$ & ns & & \\
\hline \multicolumn{6}{|l|}{ Plant health } \\
\hline NDVI rating per plot, flowering & $0.79 \pm 0.02$ & $0.70 \pm 0.01$ & $0.021^{a}$ & 46.9 & 1,4 \\
\hline \multicolumn{6}{|l|}{ Yield } \\
\hline Pod weight (g) per plant & $70.18 \pm 7.27$ & $30.15 \pm 3.96$ & $0.0164^{a}$ & 13.59 & 1,4 \\
\hline Pod weight $(\mathrm{g})$ per $12 \mathrm{~m}$ & $4280.0 \pm 252.3$ & $2189.3 \pm 284.9$ & $0.0038^{a}$ & 30.53 & 1,4 \\
\hline \multicolumn{6}{|l|}{ Pod damage by E. varivestis } \\
\hline$\%$ damaged pods & $22.00 \pm 5.29$ & $37.33 \pm 4.70$ & ns & & \\
\hline
\end{tabular}

ns indicates values are not statistically different according to an ANOVA.

${ }^{a}$ Values are significantly $(P<0.05)$ different according to an ANOVA.

with less severe beetle infestations suggests that physiological benefits were minor, if present at all.

\section{Conclusions}

The results of these experiments exemplify how differing field conditions can impact insect population dynamics, management needs and outcomes. In two of three seasons, planting TT snap beans seeds showed no clear benefits in our plots. Although our laboratory residual toxicity assays show that TT snap are toxic to $E$. varivestis, titers of the insecticide decrease below toxic levels rapidly, going from highly toxic at 13 DAS to minimally toxic at 20 DAS. In the field, overwintering beetles typically colonize snap beans at around 238 to 277 degree days, baseline $10^{\circ} \mathrm{C}\left[50^{\circ} \mathrm{F}\right]$ (Fess 2008), which normally occurs in late May or early June in western Virginia. Because snap beans are planted from early to late April, E. varivestis normally colonize beans once insecticide titers are too low for impactful suppression. However, a prolonged period of rain in the spring in 2016 delayed planting until late May, which allowed overwintered adults to colonize snap beans at first trifoliate stage. In this one season alone, the thiamethoxam treatment significantly reduced E. varivestis larval densities and damage, which led to increased yields. Additionally, our results did not show any negative impacts of seed-treatments on arthropod predators nor did this treatment cause secondary pest outbreaks.

Prophylactic use of chemical insecticides, such as neonicotinoid seed-treatments, may be unnecessary in certain systems and thus in conflict with IPM principles. Many studies have shown the potential for neonicotinoid seed-treatments to harm nontarget organisms such as arthropod pollinators and predators (Prabhaker et al. 2011, Seagraves and Lundgren 2012, Lundin et al. 2015, Douglas and Tooker 2016). Although neonicotinoid seed-treatments have shown efficacy against many snap bean pests (Nault et al. 2004, Koch et al 2005, Reisig et al. 2012), this method has not been tested for efficacy or nontarget effects in snap bean systems predominated by E. varivestis prior to this study. To prevent overuse of seed-treatments, it is imperative that researches examine these inquires in as many cropping systems as possible.

Other regions with different environmental conditions, pest complexes, and marketing objectives will have different pest management needs, and in certain areas, the use of seed-treatments may be more clearly necessary. For example, snap beans in New York and Minnesota are invaded by numerous economically damaging insects in the early season, such as potato leafhopper, seedcorn maggot, and bean leaf beetle, all of which are effectively controlled with various seed-treatments (Eckenrode et al. 1973, Nault et al. 2004, Koch et al. 2005). Additionally, snap beans grown in these regions are often sold to processing facilities, which have extremely low tolerances for the pod boring pest, European corn borer, Ostrinia nubilalis (Hübner) (Lepidoptera: Crambidae), which is also controlled with various at-seed treatments (Schmidt-Jeffris and Nault 2016).

While the results of this study neither overwhelmingly support nor reject the use of thiamethoxam seed treatments in snap beans for E. varivestis management, they do provide insight into the potential benefits and limitations of this approach. Moreover, there are other 
available methods for managing E. varivestis that may better coincide with the principles of IPM. Two nonchemical and prophylactic methods, planting beans on reflective plastic mulch (Nottingham and Kuhar 2016) and inoculative releases of the parasitoid wasp, Pediobius foveolatus Crawford (Barrows and Hooker 1981, Fess 2008), effectively suppressed E. varivestis and increase yields in field experiments. Foliar applications of narrow spectrum insecticides have also been shown to effectively reduce $E$. varivestis injury (Patton et al. 2003, Nottingham et al. 2015) and may be a better chemical control option if used at economic threshold, around $20 \%$ defoliation (Capinera et al. 1987, Fan et al. 1993). In conclusion, it is probably more cohesive with IPM principles to manage E. varivestis with a nonchemical prophylactic method followed by a foliar spray(s) if necessary.

\section{Acknowledgments}

The authors thank Jon Woogie, Hallie Harriman, Katlin Mooneyham, Liz Fread, Alex Hessler, and other employees of Virginia Tech and Kentland farm for their assistance with sampling, preparation, and maintenance of plots. Substantial funding for this research was provided by Southern SARE (Sustainable Agricultural Research and Education) project number GS13-120.

\section{References Cited}

Afifi, M., E. Lee, L. Lukens, and C. Swanton. 2015. Thiamethoxam as a seed treatment alters the physiological response of maize (Zea mays) seedlings to neighbouring weeds. Pest Manag. Sci. 71: 505-514.

Barrows, E. M., and M. E. Hooker. 1981. Parasitization of the E. varivestis (Coleoptera, Coccinellidae) by Pediobius foveolatus (Hymenoptera, Eulophidae) in urban vegetable gardens. Environ. Entomol. 10: 782-786.

Capinera, J. L., D. R. Horton, N. D. Epsky, and P. L. Chapman. 1987. Effects of plant density and late-season defoliation on yield of field beans. Environ. Entomol. 16: 274-280.

Cooper, W. R., and D. R. Horton. 2015. Effects of elicitors of host plant defenses on pear psylla, Cacopsylla pyricola. Entomol. Exp. Appl. 157: 300-306.

Douglas, M. R., and J. F. Tooker. 2015. Large-scale deployment of seed treatments has driven rapid increase in use of neonicotinoid insecticides and preemptive pest management in U.S. field crops. Environ. Sci. Technol. 49: 5088-5097.

Douglas, M. R., and J. F. Tooker. 2016. Meta-analysis reveals that seed-applied neonicotinoids and pyrethroids have similar negative effects on abundance of arthropod natural enemies. PeerJ. 4: e2776.

Eckenrode, C. J., N. L. Gauthier, D. Danielson, and D. R. Webb. 1973. Seedcorn maggot: Seed treatments and granule furrow applications for protecting beans and sweet corn. J. Econ. Entomol. 66: 1191-1194.

Fan, Y., E. Groden, M. Liebman, and R. A. Alford. 1993. Response of dry bean yield to injury by E. varivestis (Coleoptera: Coccinellidae) in low-input and conventional cropping systems. J. Econ. Entomol. 86: 1574-1578.

Fess, T. L. 2008. Organic management of E. varivestis (Epilachna varivestis Mulsant) in snap bean (Phaseolus vulgaris L.). Masters Thesis, West Virginia University. ProQuest Dissertations Publishing. Accession \#1458499.

Ford, K. A., J. E. Casida, D. Chandran, A. G. Gulevich, R. A. Okrent, K. A. Durkin, R. Sarpong, E. M. Bunnelle, and M. C. Wildermuth. 2010. Neonicotinoid insecticides induce salicylate-associated plant defense responses. Proc. Natl. Acad. Sci. U.S.A. 107: 17527-17532.

Gontijo, P. C., V. F. Moscardini, J. P. Michaud, and G. A. Carvalho. 2015. Non-target effects of two sunflower seed treatments on Orius insidiosus (Hemiptera: Anthocoridae). Pest Manag. Sci. 71: 515-522.

Howard, N. F., and B. J. Landis. 1936. Parasites and predators of the E. varivestis in the United States. 12 pp. USDA Agricultural Bulletin 418, Washington DC.

Kiman, Z. B., and K. V. Yeargan. 1985. Development and reproduction of the predator Orius insidiosus (Hemiptera: Anthocoridae) reared on diets of selected plant material and arthropod prey. Ann. Entomol. Soc. Am. 78: 464-467.
Koch, R. L., E. C. Burkness, W. D. Hutcheson, and T. L. Rabaey. 2005. Efficacy of systemic insecticide seed treatments for protection of early-growthstage snap beans from bean leaf beetle (Coleoptera: Chrysomelidae) foliar feeding. Crop Prot. 24: 734-742.

Lundin, O., M. Rundlöf, H. G. Smith, I. Fries, and R. Bommarco. 2015. Neonicotinoid insecticides and their impacts on bees: A systematic review of research approaches and identification of knowledge gaps. PLoS One. 10: e0136928.

Maienfisch, P., M. Angst, F. Brandl, W. Fischer, D. Hofer, H. Kayser, W. Kobel, A. Rindlisbacher, R. Senn, A. Steinemann, et al. 2001. Chemistry and biology of thiamethoxam: a second generation neonicotinoid. Pest Manag. Sci. 57: 906-913.

Nault, B. A., A. G. Taylor, M. Urwiler, T. Rabaey, and W. D. Hutchison. 2004. Neonicotinoid seed treatments for managing potato leafhopper infestations in snap bean. Crop Prot. 23: 147-154.

Nottingham, L. B., J. D. Aigner, J. M. Wilson, J. A. Morehead, A. DiMeglio, and T. P. Kuhar. 2015. Laboratory bioassay evaluation of IKI-3106 (cyclaniliprole) for control of E. varivestis and Japanese beetle, 2014. Arthrop. Manag. Tests. 40: 12.

Nottingham, L., and T. Kuhar. 2016. Reflective polyethylene mulch reduces E. varivestis (Coleoptera: Coccinellidae) densities and damage in snap beans. J. Econ. Entomol. 109: 1785-1792.

Nottingham, L. B., G. P. Dively, P. B. Schultz, D. A. Herbert, and T. P. Kuhar. 2016. Natural history, ecology, and management of the E. varivestis (Coleoptera: Coccinellidae) in the United States. J. Int. Pest Manage. 7: $1-12$.

O'Neil, R. J. 1989. Comparison of laboratory and field measurements of the functional response of Podisus maculiventris (Heteroptera: Pentatomidae). J. Kans. Entomol. Soc. 62: 148-155.

O’Neil, R. J., and R. N. Wiedenmann. 1990. Body weight of Podisus maculiventris (Say) under various feeding regimes. Can. Entomol. 122: 285-294.

Patton, T. W., G. P. Dively, and A. K. Miller. 2003. Evaluation of organic insecticides for control of E. varivestis on snap bean, 2002. Arthrop. Manag. Tests. 28: 1-2.

Philips, C. R., T. P. Kuhar, M. P. Hoffmann, F. G. Zalom, R. Hallberg, D. A. Herbert, C. Gonzales, and S. Elliott. 2014. Integrated pest management, in Encyclopedia of Life Sciences. John Wiley and Sons, Ltd, Chichester, England.

Prabhaker, N., S. J. Castle, S. E. Naranjo, N. C. Toscano, and J. G. Morse. 2011. Compatibility of two systemic neonicotinoids, imidacloprid and thiamethoxam, with various natural enemies of agricultural pests. J. Econ. Entomol. 104: 773-781.

Radcliffe, E. B., and W. D. Hutcheson. 2009. Integrated pest management: concepts, tactics, strategies and case studies. Cambridge University Press: Cambridge, UK.

Reisig, D. D., D. A. Herbert, and S. Malone. 2012. Impact of neonicotinoid seed treatments on thrips (Thysanoptera: Thripidae) and soybean yield in Virginia and North Carolina. J. Econ. Entomol. 105: 884-889.

SAS Institute Inc. 2007. JMP user's guide. SAS Institute Cary, NC.

Seagraves, M. P., and J. G. Lundgren. 2012. Effects of neonicitinoid seed treatments on soybean aphid and its natural enemies. J. Pest Sci. 85: $125-132$.

Schmidt-Jeffris, R. A., and B. A. Nault. 2016. Anthranilic diamide insecticides delivered via multiple approaches to control vegetable pests: a case study in snap bean. J. Econ. Entomol. 109: 2479-2488.

Stern, V. M. 1973. Economic thresholds. Annu. Rev. Entomol. 18: 259-280.

Szczepaniec, A., M. J. Raupp, R. D. Parker, D. Kerns, and M. D. Eubanks. 2013. Neonicotinoid insecticides alter induced defenses and increase susceptibility to spider mites in distantly related crop plants. PLoS ONE 8: e62620.

Taylor, A. G., C. Eckenrode, and R. Straub. 2001. Seed coating technologies and treatments for onion: challenges and progress. HortScience 36: 199-205.

Wiedenmann, R. N. and R. J. O’Neil. 1991. Laboratory measurement of the functional response of Podisus maculiventris (Say) (Heteroptera: Pentatomidae). Environ. Entomol. 20: 610-614.

Zar, J. H. 2010. Biostatistical analysis, 5th ed. Prentice Hall, NJ, pp. 944. 